https://doi.org/10.46344/JBINO.2020.v09i03.15

\title{
Study of the degree of development of erosion on sloping lands of Azerbaijan
}

\author{
Institute of Soil Science and Agrochemistry of NAS of Azerbaijan
}

Prof. RANS Z.H. Aliyev

\begin{abstract}
The article considers the probability of the intensity of the erosion process and the prerequisites for its mitigation and control. The results of the research prove that soil erosion is based on natural and anthropogenic factors. The main objectives of the study were to determine the amount and level of development of worn and erosion-prone soils in the foothills of the country, where it is very difficult to develop on the slope soils of Upper Shirvani. Therefore, in this connection, the tasks are solved, taking into account the requirements of preserving the ecological situation in the example of the Shamakhi district of the Upper Shirvan zone of the Republic of Azerbaijan, where the areas of its potential danger are identified and the preconditions for its prevention are given .
\end{abstract}

Key words: erosion, soil erosion degree; eco; erosion event. 


\section{INTRODUCTION}

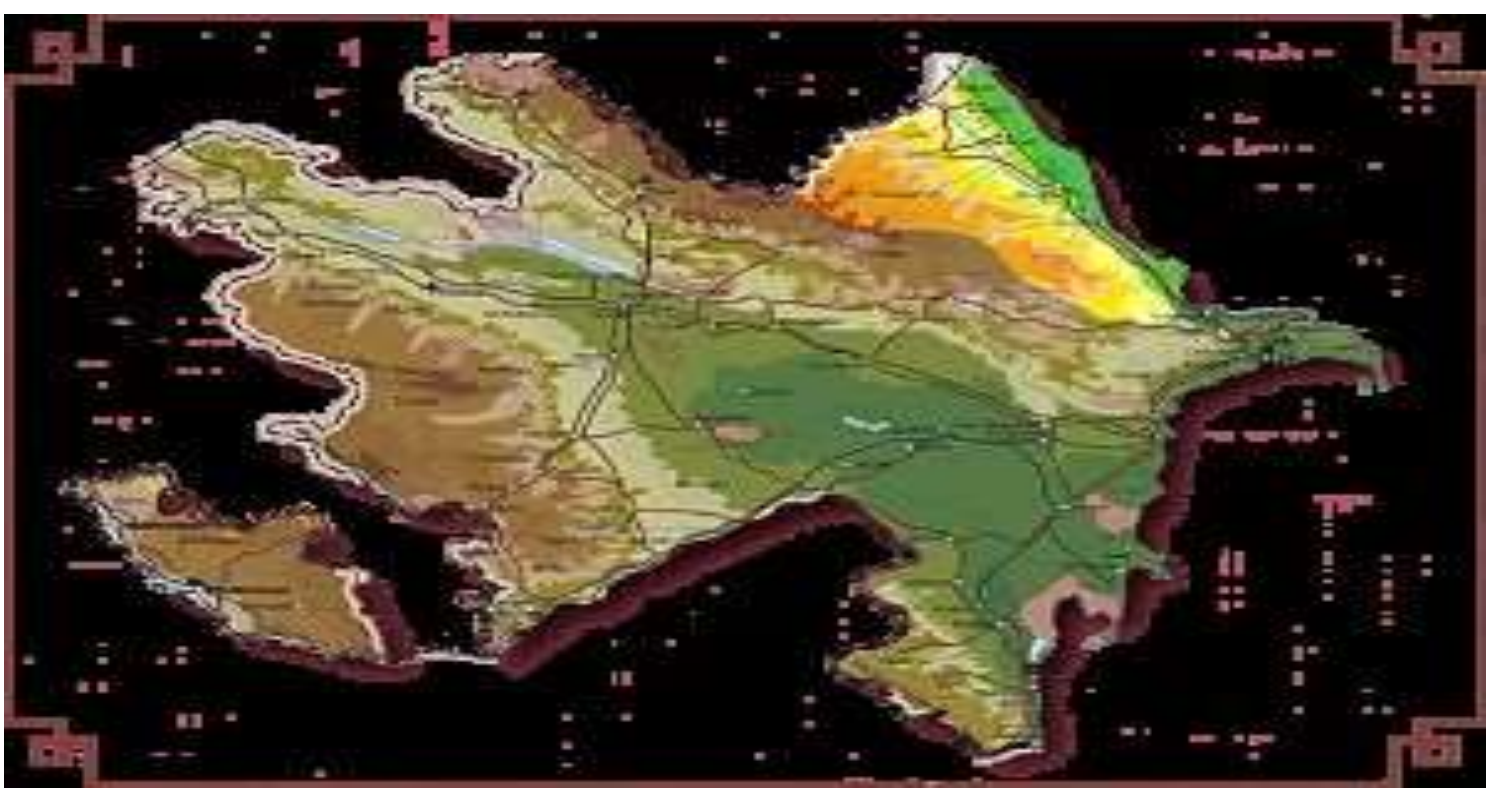

The territory of Azerbaijan is under environmental impacts the catchment of the Valley of the Caspian Sea. Here, environmental problems, which are the regional and depend on relations between States and for this reason, day after day they become strained. I must say that the soil exposed to erosion, forest plantations, mountain Grove, water sources, etc. natural education fail.

In the geological and geographic region of the study has a rather complex structure, where the high mountains and steep slopes alternate Foothill areas and Plains, which in turn contributes to the development of a fairly Motley climate the diversity of vegetation.

The complexity of the geomorphological structure, the presence of steep slopes, as well as anthropogenic forcing has a significant value of intensity of runoff, which in turn reinforces the development of erosive processes, resulting in created wide ravines, which are presented in the final stage beams, changing appearance of geomorphological region in General.

In the whole of Shirvan zone E.M. Shikhlinski [7] distinguishes 3 types of climate:

1) warm-temperate characteristic of lowland regions in area with relatively mild winters;

2) moderately warm moist type with a uniform distribution of rainfall throughout the year, covers part of the foothill zone and

3) cold climate with wet winters, characteristic of the foothills and mountain areas.

Minimum air temperature 0.50 with falls in January, and the maximum in $23.6^{\circ} \mathrm{C}$ in the month of July. The average soil temperature ranges from $-10 \mathrm{p}-30.7^{\circ} \mathrm{C}$. minimum temperature of soil in -10 with falls on January, maximum $30.0^{\circ} \mathrm{C}$ (July) and August 30.70 months. Annual rainfall is $692 \mathrm{~mm}$, most of which falls in the months of April to June. The annual value of 
evaporation $825 \mathrm{~mm}$. The average relative air humidity is $71 \%$ hesitated on the time of year from 59 to $87 \%$ [7].

Objectives of research: a study of the results of monitoring studies on determination of the degree of exposure to sloping land and establish the prerequisites for its prevention.

The moves and discuss the results of

\section{the study}

It should be recognized that the results of the many fundamental and applied research on the development of soil erosion and erosion events proved that modern methods of study inevitably and naturally it was practiced always, however, it must be said that using new works mentioned themed, opens the next stage information experimental and applied research in the field of science, where the undergone known formation ways of dealing on prevent it by an integrated approach solutions challenge studies on development of erosion of natural habitats.

It is known that is not a complete list of information on soil erosion and responses at different administrative levels overlook the content beyond the Visual and other accounting materials researchers and UNIVERSITY textbooks and may have substantial assistance to authors on many scientific and applied issues that could not be addressed fully in the Republic so far.

Direction of study on soil erosion, their mapping and designing erosionpreventive, recommended for students is wide and diverse, and may be offered basic blocks (lines): soil erosion researchterminology, classification; the criteria used to determine the risk of erosion; assessment and mapping of erosion dangerous lands; mapping of eroded soils; protection of soil from erosion; designing erosion control activities; environmental, social and economic effectiveness of erosion control measures; status of research on the issue of protecting the soil from erosion in Azerbaijan and other countries of the world.

The natural and climatic conditions of the Republic due to the water balance deficit contributes to development and erosion, deflation, and that require specific, progressive methods of development here soil, crops, land reclamation and protection without having small the Land Fund. It should be noted that in the Republic basic arrays suitable for irrigated agricultural land use is already a component of 1.410 million ha have been mastered and further expansion of arable land is only possible due to the development of less productive land that and requires excessive protection from soil erosion on the reclaimed lands, maintaining and enhancing soil fertility is of great importance for the country.

In the process of realization of scientific research conducted by the authors in the Institute Erosion and irrigation NANA on the direction of research in their monographs soil erosion is represented as a function of the natural and anthropogenic factors and its environmental consequence.

The authors assumed that each science requires some precision and clarity of concepts and achievements of new results continuously improved control 
measures and classification of objects. These issues have engaged many scholars, so for example: A.n. Zavarickij (1947); Sobolev, s.s. (1948), k.a. Alekperov D.a. (1950-1970), Khalilov M.h. (19721989)), A.a. Ibrahimov (1967-2010), Shvebs G. (1977), Belgibaev M.e. (1970), Budagov B.a. (1953-2006), Aliyev, B.H. (1990-2016); Zaslavsky (1972-1979), etc.), in the writings of which terms, derived from the word erosion as well as the concept of water and wind erosion treated very extensively and definitely not always, and, in this regard, there are many examples of their divisive the interpretation. From among the authors published their monographs are reasonably M.N. Zaslavsky, C. A. Alekperov, B.g. Aliyev who, instead of widespread term water erosion recommends the use of the term to refer to soil erosion as flushing, so soil erosion and surface run-off water flows, temporary and term deflation (confront wind) instead of wind erosion, which precisely captures the essence of the phenomenon.

Listed in the reportable materials numerous studies and monographs authors scope and geography of soil degradation, the economic damage caused by erosion of the horrifying.
Carried out major structural changes as a result of the land reforms in agriculture initiated in Azerbaijan starting with the year 1990, led to the reduction of agricultural land, the withdrawal from agricultural use vast areas of arable land and grassland degradation, covered by huge economic and environmental damage and the threat to the very existence of the soil as the principal means of production and irreplaceable component of the biosphere.

It is known that patterns of manifestations of land degradation related to climatic, lithologicgeomorphological particularities, as well as the intensity of manifestation of anthropogenic influence.

The Republic of Azerbaijan, the insufficiency of knowledge, characterised by large areas of arable land with very low humus content, high acidity, scarcity of phosphate soil regime.

The results of the study determined that in Azerbaijan land occupies sklonovye ha 3236 square.

Land distribution in natural and economic zones of the Republic on relief conditions placed as follows (table 1.) [5]. 
Table 1.

Land distribution in natural and economic areas of the Republic on relief conditions

\begin{tabular}{|c|c|c|c|c|c|}
\hline \multirow{2}{*}{$\begin{array}{l}\text { Natural- } \\
\text { economic zones }\end{array}$} & \multirow{2}{*}{$\begin{array}{l}\text { Suitable for } \\
\text { irrigated } \\
\text { land, } \\
\text { according to } \\
\text { the } \\
\text { conditions of } \\
\text { the relief }\end{array}$} & \multicolumn{4}{|c|}{ Including slopes } \\
\hline & & $<0.05$ & $0.05+0.10$ & +0.200 .10 & +0.400 .20 \\
\hline 1 & 2 & 3 & 4 & 5 & 6 \\
\hline Ganja-Kazakh & 427.50 & 251.0 & 72.8 & 63.70 & 40.00 \\
\hline Shirvan & 680.80 & 522.6 & 50.0 & 66.10 & 42.10 \\
\hline $\begin{array}{l}\text { Karabakh- } \\
\text { Milskaja }\end{array}$ & 749.00 & 567.6 & 80.20 & 47.40 & 53.80 \\
\hline $\begin{array}{l}\text { Waterless } \\
\text { Mugano- } \\
\text { Saljanskaja }\end{array}$ & 429.8 & 402.4 & 2.8 & 17.1 & 7.5 \\
\hline $\begin{array}{l}\text { Shaki- } \\
\text { Zakatalskaja }\end{array}$ & 322.7 & 236.5 & 42.7 & 23.8 & 19.7 \\
\hline Lankaran & 81.5 & 79.5 & 2.0 & - & - \\
\hline Absheron & 52.7 & 31.1 & 21.6 & - & - \\
\hline Cuba-Xacmaz & 203.5 & 179.1 & 24.4 & - & - \\
\hline Upper Garabag & 133.7 & 24.7 & 27.8 & 37.6 & 43.4 \\
\hline Nakhchivan & 154.2 & 95.3 & 38.0 & 11.2 & 9.7 \\
\hline Total Republic & 3235.4 & 2390.0 & 362.3 & 266.9 & 216.2 \\
\hline
\end{tabular}

Thus, the limited land resources is forcing even plow steep slopes. It is believed that slopes from 30 to $15^{0}$ (biases $0.05-0.25$ ) are flat, from ${ }^{0}$ to $15200 \quad(0.25-0.35)$ - transition to steep, 200 -steep. On the basis of the results of research and other scientists believed that from this boundary slopes, suitable for irrigation 216 thousand. 
hectares are located on steep slopes, 629 thousand hectares is on sites with slopes ranging from 0.05 to 0.20 and 2390 thous. ha-shallow areas with slopes $\square 0.05$.

To conclude on the slopes of $15-20^{\circ}$ place gardens and vineyards. Often sklonovye lands in $30-40^{\circ}$ degrees or greater, are used for vineyards with the direction of the rows along the slope, posing a dire conditions for exploitation of agricultural machines and enhanced flushing topsoil in the aisles.

Therefore, the author considers when laying new vineyards and orchards should not go on seemingly a more economical way of bookmarks in the direction of the slope. There is also use of steep slopes under crops grain and forage crops [2.6].

Ploughing and tillage on such areas run along the slope, which contributes to the flushing of soil and a sharp decline in its fertility.

\section{Long-term systematic not a} legitimate use of chemical plant protection products in the region, as the years of soviet power, and now especially pesticides, is one of the main problems in the agricultural zone of the
Republic as Lip-Hachmasskoj, GanjaGazakh, Upper shirvani and Holding. Pollution of the soil here has a negative impact on plants, reduce the harvest of crops and the potential loss I soil fertility.

Along with the pollution of ecosystems affected by the negative consequences for people and livestock in the region.

Environmental pollution has become one of the most important Wednesday challenges, special role where belongs to the heavy metals that have the ability to accumulate in soils and through them get into foods while promoting and soil degradation.

Zoning of the territory of the Republic on irrigation technique and degree of soil erosion in republics showed that we surveyed 14 districts have a tense situation, in which there is a risk the withdrawal of arable land here due to the heavy use in view of the complete degradation of soils.

In Azerbaijan are found all types of erosion (incl. water, mudflow, wind, surface, line, etc.) the susceptibility of soil erosion in mountain areas of Azerbaijan are listed in the table below. (see table 2). 
Table 2

\section{Exposure to soil erosion in mountain areas of Azerbaijan}

\begin{tabular}{|c|c|c|c|c|c|}
\hline \multirow[b]{2}{*}{ Areas } & \multirow[b]{2}{*}{$\begin{array}{l}\text { Total area in } \\
\text { th. HA }\end{array}$} & \multicolumn{4}{|c|}{ Including exposure to erosion } \\
\hline & & $\begin{array}{l}\text { not } \\
\text { podverzh. } \\
\text { ths. ha,\% }\end{array}$ & Little & medium & strongly \\
\hline Dashkesan & 90.3 & $23.3 / 25.8$ & $18.3 / 20.3$ & $25.6 / 28.3$ & $23.1 / 25.6$ \\
\hline Gədəbəy & 150.3 & $73.6 / 49.0$ & $20.1 / 13.4$ & 129.829 .8 & $26.8 / 27.8$ \\
\hline Lachin & 124.3 & $48.4 / 38.9$ & $27.2 / 21.9$ & $18.9 / 15.2$ & $29.8 / 24.0$ \\
\hline Lachin & 166.5 & $56.7 / 34.1$ & $26.3 / 15.8$ & $36.7 / 22.0$ & $46.8 / 28.1$ \\
\hline Kubadly & 79.8 & $25.7 / 33.5$ & $6.9 / 8.6$ & $/ 28.736 .0$ & $17.5 / 21.9$ \\
\hline Zangilan & 72.5 & $24.6 / 33.9$ & $16.4 / 22.6$ & $14.6 / 20.2$ & $16.9 / 23.3$ \\
\hline Lerik & 136.5 & $43.6 / 32.2$ & $19.4 / 14.3$ & $27.8 / 20.5$ & $44.7 / 33.0$ \\
\hline Yardimli & 12.5 & $25.1 / 34.6$ & $12.6 / 17.4$ & $10.6 / 14.6$ & $24.2 / 34.4$ \\
\hline $\begin{array}{l}\text { Mountain part } \\
\text { Goranboja }\end{array}$ & $57.6 / 20.8 / 19.5$ & $7.7 / 36.1$ & 33.9 & 13.4 & $9.6 / 16.6$ \\
\hline Julfa & 99.4 & $9.9 / 10.0$ & $16.3 / 16.4$ & $25.3 / 25.5$ & $47.9 / 48.1$ \\
\hline Shahbuz & 81.4 & $61.1 / 19.8$ & $5.4 / 6.6$ & $15.7 / 19.3$ & $14.2 / 54.3$ \\
\hline Ordubad & 92.4 & $7.0 / 7.6$ & $9.5 / 10.6$ & $13.5 / 14.6$ & $62.1 / 67.2$ \\
\hline Absheron & 535 & $57.5 / 10.7$ & $116.8 / 21.8$ & $165.5 / 30.9$ & $195.5 / 36.6$ \\
\hline
\end{tabular}

As can be seen from the table, the most common is water erosion, which Mountain soil in this and other develops in mountain regions more exposed to erosion, which covers 51.0 92.4\% land area. The Shahbuz, and Also areas of soil subjected to strong erosion and, respectively, accounted for 54.3 and $67.2 \%$. [2.6] Here there is an 
opportunity to increase irrigated lands up to $1235 \mathrm{HA}$

The above mentioned mountainous areas, thanks to the collection of mud water in small ponds, over 1300 hectares of wet or nepodvergajushhiesja farming soils hold watering, which serves to protect the mudflow and irrigation erosion in these areas. Furthermore, by reducing soil erosion, introduction of a number of activities, including provision of adequate quantities of soil mineral fertilizers in these areas can be achieved production of 35.0 thousand tons of wheat, 12.0 thousand. tons of tobacco, 10-15 thousand tons of vegetables, 95-100 thousand tons of potato, as well as through improved forage base significantly improve livestock production. $[2,3,6]$.

On the mountain and Foothill regions on sloping lands of Azerbaijan using newly developed technological means of irrigation, us has been implemented large amount of long-term research work under the supervision of B.H. Aliyev [2].

Given the above, it is recommended for mountain and Foothill areas following irrigation methods:

1. furrow irrigation with slit;

2. spray a low intensity rain sivnostju;

3. small dispersion moisturizing and without combining with sprinkler systems;

4. drip irrigation, etc.

Irrigation on furrows with slit area $\square$ 0.03. in addition to the garden for all other crops in the conditions of surface irrigation method is not recommended because wasteful water consumption. It should be noted that the establishment and development of new advanced irrigation methods is exception of irrigation erosion, conserve irrigation water and not violate environmental protection Wednesday.

From the above it follows that while mastering the slopes not only in Azerbaijan, but also in countries throughout the world requires a cautious approach to the choice of irrigation technique and technology recommended for irrigation of cultivated crops on land On slopes. conclusion on the slopes of $15-200$ place gardens and vineyards.

Often sklonovye lands in 30-400 degrees or greater, are used for vineyards with the direction of the rows along the slope, posing a dire conditions for the exploitation of agricultural machines and enhanced flushing topsoil the aisles. So is that when laying new vineyards and orchards should not go on seemingly a more economical way of bookmarks in the direction of the slope.

There is also use of steep slopes under crops grain and forage crops. [2.5] it must be recognized, however, that the effectiveness of our measures of erosion control and the prevention of erosion risk are complex defenses, promotes regulation of runoff, soil protection from Flushing, Washout, however, and the restoration and improvement of eroded soils and the involvement of eroded land in the rational use of the agriculture Republic.

\section{The conclusions of the}

1. in order to address the question raised requires differentiation of lands for their natural potential and degree of erosion and then define a set of measures to put an end to degradation and 
restoration of soil fertility with subsequent zoning of the territory of the Republic according to the degree of erosion with obligatory taking into account all factors affecting the State and land use in different types of soils of the Republic.

\section{Literature}

[1]. Aliyev G.A.Soils of the big Caucasus within the

Azerbaijan SSR,Baku,"Elm",1978,157 p.

[2]. Aliyev B.H., AliyevZ.H. Aliyev I.N.. and. Problems erosion in Azerbaijan and Said Russian ways of its solution. IZD-vo Zia-CPI "Nurlan". Baku. 122000 with

[3]. Babayev M. A. M.Jafarov, etc.-modern pochennyj cover of the Greater Caucasus, Baku, 2017, 344 p. (in Azeri language)
[4]. Biodiversity and climate diversity. AGl, UNEP, 2007. http: « www. cbd.int /doc/ bioday/2007/ibd- -2007booklet-01-ru. Pdf»/

[5]. Vernadsky V.I. works on the General history of Science [text]/V. I. Vernadsky.m.: Nauka, 1908.

[6]. Mamedov G.Sh.-land reform in Azerbaijan: legal, scientific and environmental issues, 2000, $371 \mathrm{p}$.

[7]. Mamedov R.Q.Agrofizicheskaja characteristics of soil priaraksinskoj stripes, 1970,p321.

[8]. V.E. Flint, etc.-conservation and restoration of biodiversity. M.: IZD. Scientific and educational-methodical Center, 2002, 282 p.

[9]. Shyhlinskij E.M.-climate in Azerbaijan, Baku, 1968, with 341. 